\title{
Comparative Tests of the Quality of the Piston Combustion Chamber for a Diesel Engine
}

\author{
Andrzej PACANA, Karolina CZERWIŃSKA
}

\begin{abstract}
Diesel engines are widely used despite their relatively high environmental impact. This fact requires ensuring high quality engine components, including the piston. The article presents a problem related to the occurrence of incompatibility of material structure in the combustion chamber of pistons of one of the Podkarpackie (Poland) piston factories for engines used in passenger cars. The aim of the article is to determine the diagnostic method - optimal from the point of view of quality and economy, convenient for use with large series, $100 \%$ control of the combustion chamber of pistons on the production line. Eddy current method was chosen as a solution for automatic inspection of material incompatibilities in the combustion chamber. As a complement to the selected method, a penetration method was proposed for products initially classified as non-compliant. The research was carried out in order to outline the concept of functioning of the proposed system.
\end{abstract}

Keywords: diesel engine; eddy current test; non-destructive testing; penetration test; quality testing

\section{INTRODUCTION}

The continuous development of the technology leads to a continuous increase in the loads of used machinery and equipment, which necessitates an increase in the requirements for construction materials and the introduction of new technological solutions. This development undoubtedly has a significant impact on new technologies for the production of metals and alloys with higher strength properties $[1,2]$.

The engine that drives all motor vehicles undergoes constant modernization not only on a micro scale but also on a macro scale. On a micro scale, the changes relate to engine design solutions. Examples of this type of change include the piston of the internal combustion engine operating under cyclic temperature changes. Due to high temperature loads, it should have high technological and structural properties as well as mechanical properties. This is done by modifying the chemical composition, i.e. changes in the amount and type of alloying additives, their proportions and by the application of a suitable technological process. Macro-scale changes are observed over a longer period of time. The construction of the steam engine, which took place in the 19th century, has been a driving force for the development of motor vehicles. The first units were characterized by low turnover, high internal weight, low efficiency, as well as adaptation to the use of solid fuel. These disadvantages have contributed to the introduction of newer and more technologically advanced solutions. A piston-type internal combustion engine was formed, which differed primarily by the fuel combustion process moving towards the center of the cylinder. The crankshaft system was borrowed from the steam engine design [3].

Currently diesel engines are used almost in all industrial vehicles and in a growing number of cars, mainly due to the low cost of their operation. Unfortunately, such engines are the source of exhaust fumes dangerous to human health and the environment [4].

Detection and removal of non-compliant products is essential from the perspective of the interests of diesel piston manufacturers [5], as well as the requirements of technical safety systems [6-8]. Non-destructive testing becomes a commonly used tool to ensure the reliability of products by detecting non-conformity in the product during an inprocess control or in the finished product and not allowing it to be used. However, there is no universal method and the individual diagnostic methods complement each other [9]. Each non-destructive testing method has its advantages, disadvantages and limitations.

In order to select the optimal, from the qualitative and economic point of view, method of detecting material incompatibilities of the piston combustion chamber intended for the construction of the "zero deficiencies" system in the manufacturing process, methods that meet the requirement of applicability on the production line for large series production have been presented. Due to the significant number of complaints received by the company, within the last two quarters, it was decided to take action to introduce a system of "zero deficiencies" in the production of the most emergency type of product.

\section{EDDY CURRENT METHOD}

The eddy current method is a non-destructive surface test. This method makes it possible to detect the most dangerous type of discontinuity: surface flat discontinuities, narrow-banded and relatively large located near the surface of subsurface discontinuities. However, the possibility of detecting the last discontinuities should not be overestimated [9-11].

Non-destructive testing method with the use of eddy currents with measurement in the so-called. RFEC was originally used in the field for testing heat exchanger tubes [12].

In this method, the magnetic field changes in time, generating the generation of vortex currents that flow axially and circumferentially in the examined object [13]. Thanks to the Lenza rule and the Faraday phenomenon, a secondary magnetic field counteracts the inducing factor. Due to the phenomenon of so-called surface effect and geometry of the object under study, concentration of the field of eddy currents - area of the highest intensity covers the area at the excitation coil. However, due to the current flow in the studied object, the generated magnetic field has a much wider range. This action leads to the formation of magnetic field dominance from the eddy currents (secondary magnetic field) in a zone away from the measurement coil and above the magnetic field produced by the induction coil.

For the generation of swirling currents, an RF2 probe is used in which the flowing alternating current induces a 
variable magnetic field. This probe is equipped with two measuring coils, i.e. excitation and recording.

In the RFEC test, the recording coil is located at a certain distance from the excitation coil in the zone in which the dominant magnetic field is the field from the excited currents. In other words, the measurement area is the recording of only the secondary magnetic field. On the other hand, registration of changes in the secondary field by changing the voltage generated in the recording coil gives the possibility to determine changes in the examined element. The magnetic field in this zone is significantly weaker (with less intensity) than in the area of the excitation coil - but all heterogeneities in the discontinuity of the material or pollutions are recorded.

\section{PENETRATION METHOD}

Penetration test is a simple and fast non-destructive test that allows the detection of surface discontinuities ranging from 10-6 m, such as grinding cracks, fatigue cracks, porosity, pitting, delamination, cracks resulting from forging or after rolling. The penetration method uses the capillary phenomenon i.e. penetration of the penetrant indicating liquid, into the defects present in the examined surface (cracks, crevices, pores, cracks). After cleaning the surface of the object from the excess penetrant and drying it, a thin, white developer layer is applied. The developer's task is to "pull out" the penetrant from the defect and thereby make it visible in the form of colored, rounded or linear indications. Commonly used for this type of study are penetrant colors (red) or fluorescent. Where fluorescence penetrants are used to produce fluorescence and surface discontinuity, ultraviolet lamps are used. Dyes of this type under the influence of UV radiation are usually light yellow and green and are clearly visible on a dark background. In this method it is necessary to darken the research station to increase the detection of defects [14].

Penetration method is used in ferromagnetic materials as non-ferromagnetic (steel, cast steel, copper, cast iron, brass, tungsten, bronze) and non-metallic materials (e.g. ceramic).

The advantages of penetration testing are undoubtedly the rapid and simple testing process, the possibility of testing different materials, products of any shape and size and the relative ease of detecting defects of about $0.001 \mathrm{~mm}$. The advantages are also the ease to judge the indications and ease of use in workshop or field conditions. A great advantage of this method is the low cost of the test, the possibility of mechanization of the test process and the high efficiency of defect detection [15].

Among the disadvantages of the penetration method is the need to pre-clean and degrease the surface of the tested object, as well as to clean the surface after the test. This method only detects open defects. The disadvantages include also the influence of the temperature of the tested object on the properties of the used preparations and the aging of the preparations or the possibility of toxicity of the preparations and therefore the need to ensure good ventilation during use in closed rooms [9].

\section{SUBJECT OF STUDY}

The subject of the study was a combustion chamber for piston for a diesel engine (diesel engine) used in cars, Toyota. The model of the diesel engine piston is shown in Fig. 1.

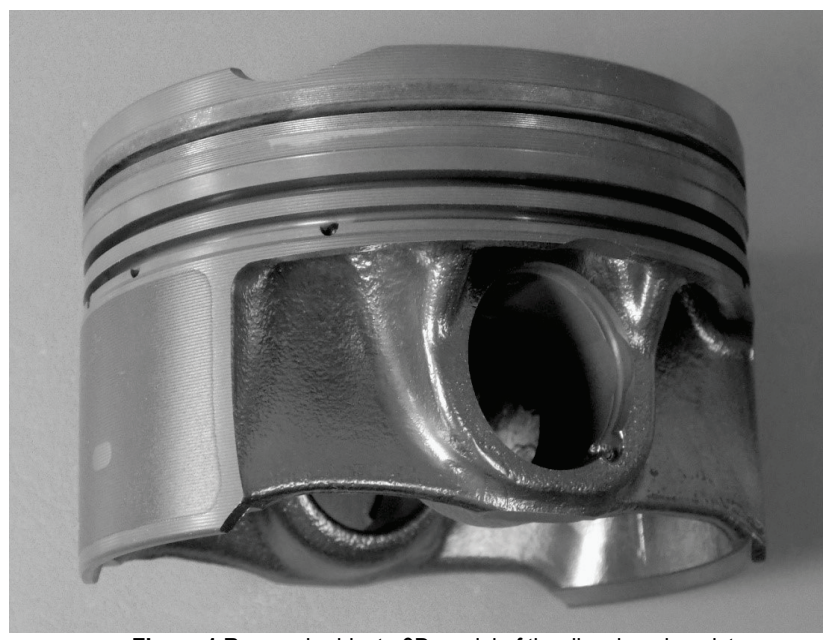

Figure 1 Research object - 3D model of the diesel engine piston

Pistons are produced in one of the plants in Podkarpacie. The piston die is made of alloy B2 (alloy AlSiCuMgNi). The range of chemical composition of alloy $\mathrm{B} 2$ is given in Tab. 1 .

The melt was made on the basis of a charge, which constituted an aluminum sponge, magnesium or manganese alloy, and a maximum of $30 \%$ recycled scrap.

Table 1 Chemical composition of alloy B2

\begin{tabular}{|c|c|c|c|c|c|c|c|c|c|c|c|c|}
\hline Composition & $\mathrm{Si}$ & $\mathrm{Cu}$ & $\mathrm{Mg}$ & $\mathrm{Ni}$ & $\mathrm{Fe}$ & $\mathrm{Mn}$ & $\mathrm{Zn}$ & $\mathrm{Pb}$ & $\mathrm{Sn}$ & $\mathrm{Ti}$ & $\mathrm{Zr}$ & $\mathrm{V}$ \\
\hline $\operatorname{Min} / \%$ & 12,0 & 3,7 & 0,5 & 1,7 & - & - & - & - & - & - & - & - \\
\hline $\operatorname{Max} / \%$ & 14,5 & 5,2 & 1,5 & 3,2 & 0,7 & 0,2 & 0,1 & 0,08 & 0,1 & 0,2 & 0,2 & 0,2 \\
\hline
\end{tabular}

The durability of the combustion chamber located in the bottom of the piston of the diesel engine often determines the maximum temperatures and safe pressures. There is a risk of fatigue rupture of the edge and base of the chamber, starting on the free silicon particles in aluminum [16]. The patented DuraBowl process utilizes a controlled recalibration of the bottom edge and / or base of the chamber in the piston rod to increase silicon grain to just one tenth of its original size, which greatly improves the fatigue life of the piston mold.

\section{RESEARCH RESULTS AND THEIR ANALYSIS}

The results of the eddy current tests of the combustion chamber in the piston of the diesel engine are presented in Fig. 2. The obtained results show the areas with discontinuities in the combustion chamber.

In order to confirm the results of eddy current tests, the penetration tests of the combustion chamber of the piston were performed. Localized areas with continuities are unacceptable, so samples were taken from the discontinuity areas and a metallographic test was 
performed. The results of the observation of the cut piston after the penetration tests and the metallographic findings are presented in Fig. 3.

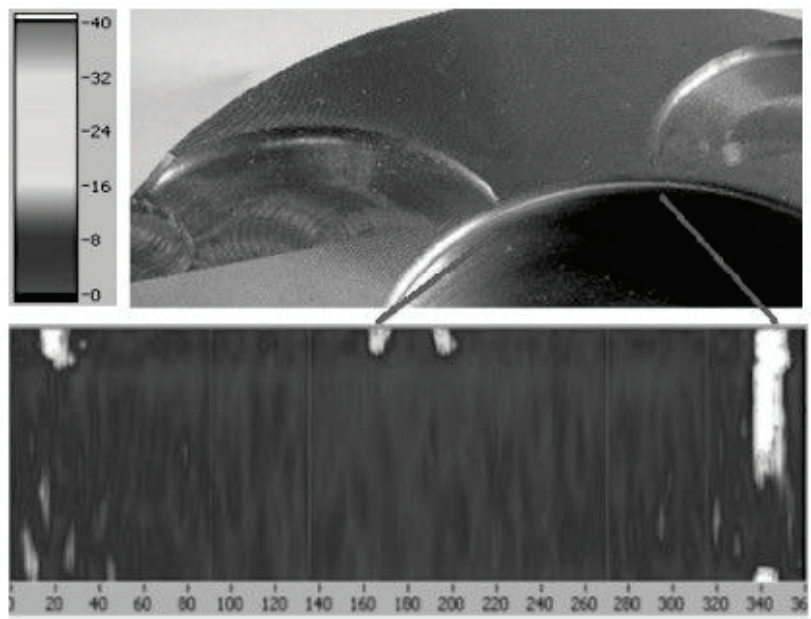

Figure 2 Results of eddy current tests of combustion chamber of diesel engine piston

The metallographic drawings allowed showing the localized discontinuities of the material. In addition to the two areas where there were three discontinuities in the combustion chamber area, the penetration tests allowed us to locate areas with additional discontinuities (Fig. 3), which, however, did not exceed the maximum permissible values according to norm in TS1E-010-011-0000.

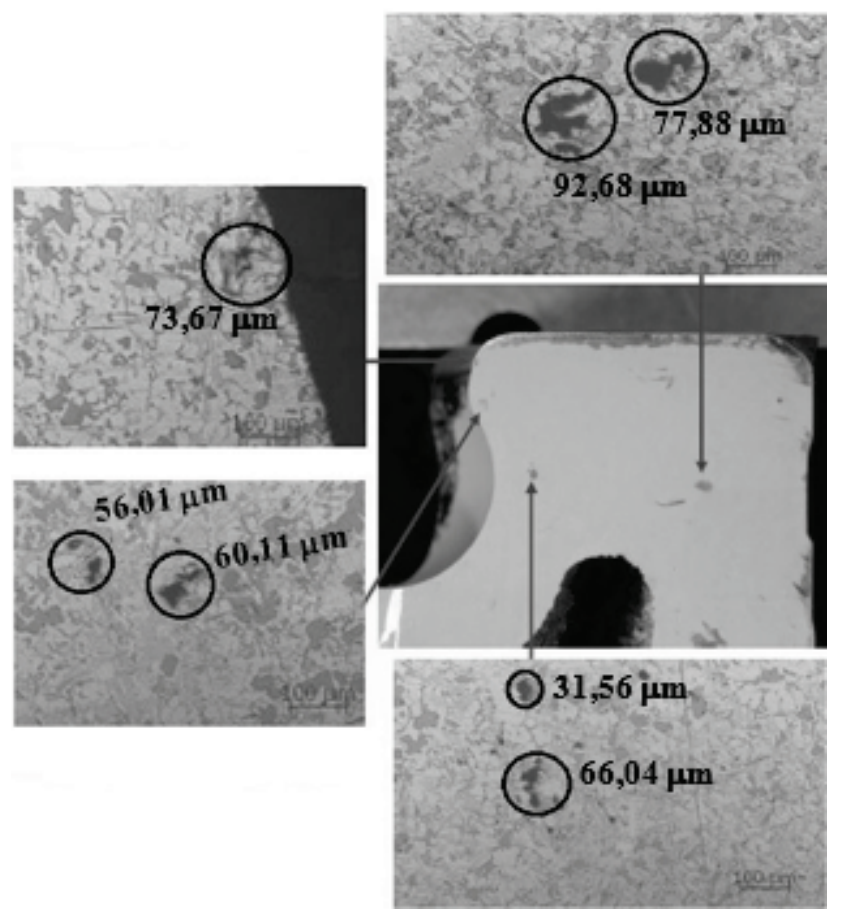

Figure 3 Results of observation of cut piston after penetration and metallographic examination

\section{CONCLUSION}

Detection of internal material incompatibilities using a zero-defect system can be achieved using highly efficient non-destructive methods.

Non-destructive electromagnetic (magnetic-inductive) methods allow for the automation of tests, allowing for accurate scanning of the tested surfaces. Therefore, the eddy current method was chosen for the automatic inspection of material incompatibilities in the combustion chamber. As a complement to the selected method in the diagnostic system, a penetration method has been proposed for devices initially classified as non-compliant. Thanks to the penetration method it is possible to detect flat, narrowslit surface discontinuities in the automated system.

The advantage of the proposed diagnostic system is the universal character of detection of geometric and structural incompatibilities (surface and subsurface) of the combustion chamber of pistons. The versatility of the method allows it to be applied in the control of all types of pistons (made of ferromagnetics) during their production (on-line).

The limitations of the proposed solution are limitations of individual non-destructive methods, i.e. eddy current diagnostics is associated with inconveniences resulting from the fact that defects such as delamination or cracks lying parallel to the course of the probe coil winding and testing direction are poorly detectable. On the other hand, the inconvenience of the penetration method is the detection of only open incompatibilities.

Application of the "zero-deficiency" system with the use of the proposed non-destructive tests contributed to the elimination of complaints about damage to the piston combustion chamber caused by manufacturing defects.

\section{REFERENCES}

[1] Weroński, A. (1983). Zmęczenie cieplne metali. Przegląd Mechaniczny, 3.

[2] Korzynski, M., Dzierwa, A., Pacana, A., \& Cwanek, J. Fatigue strength of chromium coated elements and possibility of its improvement with ball peening. Surface \& coatings technology, 204(5), 615-620. https://doi.org/10.1016/j.surfcoat.2009.08.049

[3] Weroński, A. (1983). Zmęczenie cieplne metali. Wydawnictwa WNT.

[4] Pośniak, M., Zapór, L., \& Brochocka, A. (2010). Zagrożenia spalinami silników diesla. Wydawnictwa CIOP PIB.

[5] Zbrowski, A. (2010). Contemporary methods and research apparatus for the support of technical safety systems. Innovative Technological Solutions for Sustainable Development.

[6] Zbrowski, A. \& Rogoś, E. (2011). Stan wiedzy w obszarze technologii bezpieczeństwa technicznego i środowiskowego. Rozdział w monografii: Techniczne Wspomaganie Zrównoważonego Rozwoju. Kierunki Badawcze i Aplikacyjne. Redakcja A. Mazurkiewicz. Wydawnictwo Naukowe Instytutu Technologii Eksploatacji - PIB, Radom.

[7] Pacana, A., Gazda, A., \& Życzyński, N. (2018). Monitoring the process of anodising of VW70U pistons using the control chart. Metalurgija, 57(4), 349-352.

[8] Pacana, A., Czerwińska, K., \& Bednarova, L. (2018). Discrepancies analysis of casts of diesel engine piston. Metalurgija, 57(4), 324-326.

[9] Lewińska-Romicka, A. (2011). Badanianie niszczace. Podstawy defektoskopii. Wydawnictwo NaukowoTechniczne, Warszawa.

[10] Tian, L. S., Guo, Y. C., Li, J. P., Wang, J. L., Duan, H. B., Xia, F., \& Liang, M. X. (2018). Elevated re-aging of a piston aluminium alloy and effect on the microstructure and mechanical properties. Materials Science and Engineering: A, 738. https://doi.org/10.1016/j.msea.2018.09.078 
[11] Gil, N., Konovalov, G., \& Mayorov A. (2011). Devices for non-destructive testing of adhesion quality of a Ni-resist insert in diesel engine pistons. Previous Experience and Current Innovations in Non-Destructive Testing.

[12] Dragan, K., \& Synaszko, P. (2009). In-Service Flaw Detection and Quantification in the Composite Structures of Aircraft. Fatigue of Aircraft Structures, 2009(1), 37-41. https://doi.org/10.2478/v10164-010-0003-0

[13] Dragan, K. \& Klimaszewski, S. (2005). Modern techniques for rapid crack detection in aircraft skin structure. 8 Międzynarodowa Konferencja Diagnostyka samolotów $i$ śmigłowców Airdiag 2005, 27-28.

[14] Zientek P. (2016). Metody badań nieniszczących wybranych elementów konstrukcji turbozespołu małej mocy w Maszyny Elektryczne - Zeszyty Problemowe Nr 3/2016, Politechnika Śląska, Gliwice.

[15] http://www.stalnierdzewna.com/bazawiedzy/metodybadan-penetracyjnych/ (Accessed: 18.11.2018)

[16] Jiang, D. L., Tan, S. H., Wang, J. H., Li, Y. L., Xu, Y. J., \& Cui, D. Q. (1991). Fabrication and testing of a siliconcarbide piston and cylinder for diesel-engine, Elsevier ApplSciPubl Ltd, Barking Essex, Goteborg, Sweden. https://doi.org/10.1007/978-94-011-2882-7_124

\section{Contact information:}

Andrzej PACANA, PhD, Associate Professor

(Corresponding author)

Faculty of Mechanical Engineering and Aeronautics,

Rzeszow University of Technology,

Al. Powstańców Warszawy 12, 35-959 Rzeszów, Poland

E-mail: app@prz.edu.pl

Karolina CZERWIŃSKA, MSC

Faculty of Mechanical Engineering and Aeronautics,

Rzeszow University of Technology,

Al. Powstańców Warszawy 12, 35-959 Rzeszów, Poland

E-mail: ktczerwinska@vp.pl 